\title{
Prevalence of Intestinal Protozoans among Schoolchildren in Suburban Areas near Yangon, Myanmar
}

\author{
Min-Jae Kim¹, Bong-Kwang Jung1', Jaeeun Cho², Deok-Gyu Kim¹, Hyemi Song², Keon-Hoon Lee², Seon Cho², \\ Thi Thi Htoon ${ }^{3}$, Htay Htay Tin ${ }^{3}$, Jong-Yil Chai',2,* \\ ${ }^{1}$ Department of Parasitology and Tropical Medicine, Seoul National University College of Medicine, Seoul 03080, Korea; ${ }^{2}$ Korea Association of \\ Health Promotion, Seoul 03722, Korea; ${ }^{3}$ National Health Laboratory, Yangon 11191, Myanmar
}

\begin{abstract}
Although intestinal protozoans are common etiologies of diarrhea, few studies have been conducted in Myanmar. This study planned to investigate the prevalence of Giardia lamblia, Entamoeba coli, Entamoeba histolytica, and Endolimax nana among schoolchildren and their guardians in suburban areas near Yangon, Myanmar. We performed a cross-sectional survey among schoolchildren and their guardians from 7 primary schools in South Dagon and Hlaing Thar Yar districts, Yangon, Myanmar. Stool samples were observed with a microscope after concentration technique and iodine staining. Total 821 stool samples, including 556 from schoolchildren and 265 from guardians, were examined. The median age was 6 years old for schoolchildren and 36 years old for guardians. A $53.1 \%$ of the school children and 14.6 $\%$ of the guardians were males. The overall prevalence of each intestinal protozoan species was as follows: $3.4 \%$ (28/821) for G. lamblia; 3.5\% (29/821) for E. coli; $1.2 \%$ (10/821) for E. histoytica, and 3.0\% for E. nana. This study showed that intestinal protozoans are common in primary schoolchildren and their guardians in suburban areas near Yangon, Myanmar. Health interventions, such as hand washing education, improvement of sanitation, and establishment of water purification systems are urgently needed in this area.
\end{abstract}

Key words: Giardia lamblia, Entamoeba histolytica, Entamoeba coli, Endolimax nana, prevalence, schoolchildren, Myanmar

Diarrheal diseases are important causes of morbidity and mortality in young children [1]. Diarrhea can be caused by various pathogens, including bacteria, viruses, and protozoans. Among the protozoans, Cryptosporidium species, Giardia lamblia (synonymous with G. duodenalis and G. intestinalis) and Entamoeba histolytica are well known etiologies of the human diarrheal diseases [2]. These protozoans are distributed worldwide and more prevalent in areas with poor sanitation, including southeastern Asia [3,4]. Although a previous study reported the prevalence of intestinal protozoans from the Burmese immigrants working in Thailand, the infection status of Burmese people residing in Myanmar with these protozoans has not been known [5]. In this study, we performed a cross-sectional survey to identify the prevalence of intestinal protozoans among Burmese people near Yangon, Myanmar.

The study participants were schoolchildren and their guard-

\footnotetext{
- Received 5 April 2016, revised 25 May 2016, accepted 25 May 2016.

*Corresponding author (cjy@snu.ac.kr)

(C) 2016, Korean Society for Parasitology and Tropical Medicine

This is an Open Access article distributed under the terms of the Creative Commons

Attribution Non-Commercial License (http://creativecommons.org/licenses/by-nc/4.0) which permits unrestricted non-commercial use, distribution, and reproduction in any

medium, provided the original work is properly cited.
}

ians from 7 primary schools in South Dagon and Hlaing Thar Yar district, Yangon, Myanmar (Fig. 1), and the study was done in 2015. Stool samples were collected from the participants, 1 sample per person, and fixed with sodium acetate-acetic acidformalin (SAF) solution. The mixture was filtered through gauze and centrifuged at $800 \mathrm{~g}$ for $10 \mathrm{~min}$ twice. The sediment was finally fixed with a small amount of $10 \%$ formalin and moved onto a slide glass. The slides were observed under a microscope after iodine staining. The cysts of intestinal protozoans, such as G. lamblia, E. histolytica, Entamoeba coli, and Endolimax nana were identified according to their typical morphologies.

A total of 821 people consisting of 556 schoolchildren and 265 guardians submitted their stool samples (Table 1). The median age was 6 years (interquartile range, IQR; 5-7) for the schoolchildren and 36 (IQR; 30-41) for the guardians. With regard to gender, $53.1 \%$ of the schoolchildren and $14.6 \%$ of the guardians were males. The overall positive rate for protozoan cysts was $10.0 \%$; the rate was $10.6 \%$ for schoolchildren and $8.7 \%$ for guardians (Table 2). Among the schoolchildren, the prevalence of each protozoan species was as follows: $4.3 \%$ (24/556) for G. lamblia, 3.1\% (17/556) for E. coli, 3.1\% 


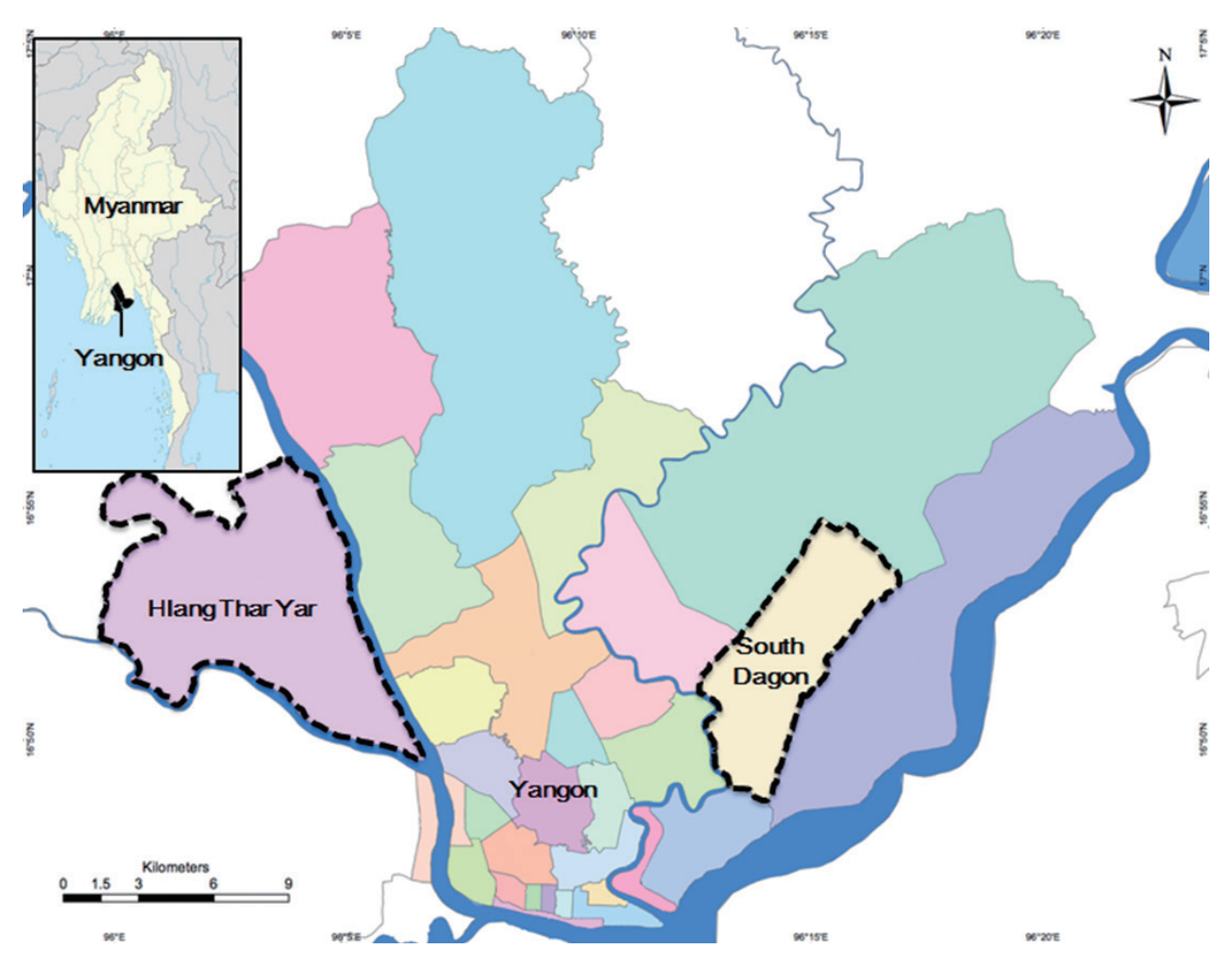

Fig. 1. Map showing the study location, suburban areas of Yangon, Myanmar. Seven primary schools in the 2 communes (South Dagon and Hlaing Thar Yar) were included in this study.

Table 1. Demographic characteristics of the study population

\begin{tabular}{|c|c|c|c|}
\hline & Schoolchildren (\%) & Guardians (\%) & Total (\%) \\
\hline Enrolled no. & $556(67.7)$ & 265 (32.3) & $821(100.0)$ \\
\hline $\begin{array}{l}\text { Age }^{\mathrm{a}} \\
\quad \text { Median; IQR }\end{array}$ & $6 ; 5-7$ & $36 ; 30-41$ & \\
\hline \multicolumn{4}{|l|}{ Sex } \\
\hline Male & $292(53.1)$ & 23 (14.6) & 315 (44.5) \\
\hline Female & $258(46.9)$ & $135(85.4)$ & 393 (55.5) \\
\hline
\end{tabular}

$I Q R$, interquartile range.

${ }^{a}$ Age information available in 636 participants.

bSex information available in 708 participants

(17/556) for E. nana, and $0.9 \%$ (5/556) for E. histolytica. In comparison, among the guardians, the prevalence was $4.5 \%$ (12/265) for E. coli, 3.0\% (8/265) for E. nana, 1.9\% (5/265) for $E$. histolytica, and $1.5 \%$ (4/265) for G. lamblia (Table 2). In South Dagon, the schoolchildren in 3 primary schools showed overall prevalences of $7.2-12.7 \%$ compared to $6.5-20.0 \%$ of schoolchildren in 4 primary schools in Hlaing Thar Yar (Table. 3). G. lamblia was more prevalent in Hlaing Thar Yar than in South Dagon (7.1\% vs 2.0\%, $P=0.003$ ) in schoolchildren. Boys revealed higher prevalences of $E$. coli ( $4.1 \%$ vs $1.8 \%$, $P=0.006)$ and E. histolytica $(1.3 \%$ vs $0.5 \%, P=0.035)$ when analyzed by the chi-square test.

In this study, we showed that overall $10 \%$ of the schoolchildren and their guardians were positive for intestinal protozoans in primary schools near Yangon. Protozoans with human pathogenic potential, such as G. lamblia and E. histolytica, were also prevalent in $3.4 \%$ and $1.2 \%$, respectively. So far as we know, this is the first report on the prevalence of intestinal protozoans among schoolchildren in Myanmar.

The prevalences of intestinal protozoans among schoolchildren in this study were similar to those reported from schoolchildren in Cambodia $[6,7]$. The prevalences of G. lamblia and E. histolytica were $2.9-3.2 \%$ and $0.8 \%$, respectively, in Cambodia $[6,7]$. In Thailand, G. lamblia was positive in $2.2 \%$ of some population in rural provinces and $6.5 \%$ of schoolchildren in suburban provinces [8]. Collectively, the prevalences of intestinal protozoans in Myanmar were similar to those from neighboring countries. However, it is of note that Myanmar immigrants working in Thailand revealed a higher prevalence (14.1\%) of G. lamblia than in this study [5]. This suggests 2 possibilities. One is that intestinal protozoan infections may be more highly prevalent in rural areas of Myanmar (possibly their hometowns), whereas the subjected areas in this study 
Table 2. Prevalence of intestinal protozoans among primary schoolchildren and their guardians

\begin{tabular}{lccccrrr}
\hline & Total no. examined & No. (\%) positive for any protozoa & E. histolytica (\%) & E. coli (\%) & E. nana (\%) & G. lamblia (\%) \\
\hline Schoolchildren & 556 & $59(10.6)$ & $5(0.9)$ & $17(3.1)$ & $17(3.1)$ & $24(4.3)$ \\
Guardians & 265 & $23(8.7)$ & $5(1.9)$ & $12(4.5)$ & $8(8.0)$ & $4(1.5)$ \\
Total & 821 & $82(10.0)$ & $10(1.2)$ & $29(3.5)$ & $25(3.0)$ & $28(3.4)$ \\
\hline
\end{tabular}

Table 3. Prevalence of intestinal protozoans among primary schoolchildren according to school

\begin{tabular}{llcccccc}
\hline District & School & Total no. examined & No. (\%) positive for any protozoa & E. histolytica (\%) & E. coli (\%) & E. nana (\%) & G. lamblia (\%) \\
\hline Hlang Thar Yar & BEPS 6 & 54 & $7(13.0)$ & $1(1.9)$ & $3(5.6)$ & $0(0.0)$ & $5(4.8)$ \\
Hlang Thar Yar & BEPS 10 & 45 & $9(20.0)$ & $0(0.0)$ & $2(4.4)$ & $3(6.7)$ & $6(4.8)$ \\
Hlang Thar Yar & BEPS 14 & 77 & $5(6.5)$ & $1(1.3)$ & $1(1.3)$ & $1(1.3)$ & $3(3.9)$ \\
Hlang Thar Yar & BEMS 28 & 76 & $7(9.2)$ & $0(0.0)$ & $0(0.0)$ & $1(1.3)$ & $6(6.7)$ \\
South Dagon & BEPS 19 & 61 & $7(11.5)$ & $1(1.6)$ & $0(0.0)$ & $5(8.2)$ & $1(1.1)$ \\
South Dagon & BEPS 21 & 125 & $9(7.2)$ & $0(0.0)$ & $2(1.6)$ & $6(4.8)$ & $2(1.2)$ \\
South Dagon & Ywar Thar Gyi & 118 & $15(12.7)$ & $2(1.7)$ & $9(7.6)$ & $1(0.8)$ & $3(2.5)$ \\
Total & & 556 & $59(10.6)$ & $5(0.9)$ & $17(3.1)$ & $17(3.1)$ & $24(4.3)$ \\
\hline
\end{tabular}

BEPS, Basic Education Primary School; BEMS, Basic Education Middle School.

were suburban areas near Yangon. Another possibility is that Myanmar immigrant workers were more frequently exposed to fecal-oral contamination of food or water either in specific localities of Myanmar or Thailand.

It is also interesting to see that whereas the overall prevalence was similar between the 2 surveyed districts in this study, G. lamblia was more highly prevalent in Hlaing Thar Yar than in South Dagon. In general, intestinal protozoans are considered to be prevalent in areas with poor sanitation and low socioeconomic status. Out of the 2 districts included in our study, Sough Dagon is generally known as the one with poorer socioeconomic status than Hlaing Thar Yar. Our previous study on Enterobius vermicularis identified significantly higher prevalence among children in South Dagon than in Hlaing Thar Yar [9]. Since the results of this study does not agree with this general concept, specific cause of fecal-oral contamination of G. lamblia in primary schoolchildren in Hlang Thar Yar district needs to be further elucidated.

Our study has several limitations. First, since cysts of Entamoeba dispar and Entamoeba moshkovskii have indistinguishable morphology from that of $E$. histolytica, the prevalence of $E$. histolytica could have been overestimated [10]. Second, we could not differentiate symptomatic infections from asymptomatic carrier states due to lack of clinical information. Despite these limitations, our study adds valuable information on the current status of intestinal protozoan infections among the people in Myanmar. The high prevalence of pathogenic protozoa implies that health interventions, such as hand washing education, improvement of sanitation, and establishment of water purification systems are urgently needed in these areas.

\section{ACKNOWLEDGMENT}

We are grateful to the staff of the subjected primary schools in South Dagon and Hlaing Thar Yar, Myanmar for their assistance in guidance of the schoolchildren and collection of stool samples.

\section{CONFLICT OF INTEREST}

The authors declare that they have no conflict of interest related to this study.

\section{REFERENCES}

1. Liu L, Johnson HL, Cousens S, Perin J, Scott S, Lawn JE, Rudan I, Campbell H, Cibulskis R, Li M, Mathers C, Black RE. Global, regional, and national causes of child mortality: an updated systematic analysis for 2010 with time trends since 2000. Lancet 2012; 379: 2151-2161.

2. Kotloff KL, Nataro JP, Blackwelder WC, Nasrin D, Farag TH, Panchalingam S, Wu Y, Sow SO, Sur D, Breiman RF, Faruque AS, Zaidi AK, Saha D, Alonso PL, Tamboura B, Sanogo D, Onwuchekwa U, Manna B, Ramamurthy T, Kanungo S, Ochieng JB, Omore R, Oundo JO, Hossain A, Das SK, Ahmed S, Qureshi S, Quadri F, Adegbola RA, Antonio M, Hossain MJ, Akinsola A, Mandomando I, Nhampossa T, Acacio S, Biswas K, O'Reilly CE, Mintz ED, Berkeley LY, Muhsen K, Sommerfelt H, Robins- 
Browne RM, Levine MM. Burden and aetiology of diarrhoeal disease in infants and young children in developing countries (the Global Enteric Multicenter Study, GEMS): a prospective, case-control study. Lancet 2013; 382: 209-222.

3. Bercu TE, Petri WA, Behm JW. Amebic colitis: new insights into pathogenesis and treatment. Curr Gastroenterol Rep 2007; 9: 429-433.

4. Feng Y, Xiao L. Zoonotic potential and molecular epidemiology of Giardia species and giardiasis. Clin Microbiol Rev 2011; 24: 110-140.

5. Nuchprayoon S, Sanprasert V, Kaewzaithim S, Saksirisampant W. Screening for intestinal parasitic infections among Myanmar migrant workers in Thai food industry: a high-risk transmission. J Immigr Minor Health 2009; 11: 115-121.

6. Lee KJ, Bae YT, Kim DH, Deung YK, Ryang YS, Kim HJ, Im KI, Yong TS. Status of intestinal parasites infection among primary school children in Kampongcham, Cambodia. Korean J Parasi- tol 2002; 40: 153-155.

7. Park SK, Kim DH, Deung YK, Kim HJ, Yang EJ, Lim SJ, Ryang YS, Jin D, Lee KJ. Status of intestinal parasite infections among children in Bat Dambang, Cambodia. Korean J Parasitol 2004; 42: 201-203.

8. Wongjindanon N, Suksrichavalit T, Subsutti W, Sarachart T, Worapisuttiwong $\mathrm{U}$, Norramatha P. Current infection rate of Giardia lamblia in two provinces of Thailand. Southeast Asian J Trop Med Public Health 2005; 36 (suppl 4): 21-25.

9. Chai JY, Yang SK, Kim JW, Choi SL, Song GY, Jung BK, Kim MJ, Cho J, Kim DG, Sohn WM, Jeoung HG, Cho S, Park JB, Hong S, Htoon TT, Tin HH. High prevalence of Enterobius vermicularis infection among schoolchildren in three townships around Yangon, Myanmar. Korean J Parasitol 2015; 53: 771-775.

10. Fotedar R, Stark D, Beebe N, Marriott D, Ellis J, Harkness J. Laboratory diagnostic techniques for Entamoeba species. Clin Microbiol Rev 2007; 20: 511-532. 